\title{
Myotonic dystrophy type 1: frequency of ophthalmologic findings
}

\author{
Distrofia miotônica tipo 1: frequência dos achados oftalmológicos \\ Karin Suzete Ikeda ${ }^{1}$, Cristina Iwabe-Marchese², Marcondes Cavalcante França Jr.2., Anamarli Nucci², Keila \\ Monteiro de Carvalho'
}

\begin{abstract}
The purpose of the study was to evaluate the frequency of ophthalmologic abnormalities in a cohort of myotonic dystrophy type 1 (DM1) patients and to correlate them with motor function. We reviewed the pathophysiology of cataract and low intraocular pressure (IOP). Method: Patients were included after clinical and laboratory diagnosis and after signed informed consent. They were evaluated by Motor Function Measure scale, Portuguese version (MFM-P) and ophthalmic protocol. Results: We evaluated 42 patients aged 17 to 64 years (mean $40.7 \pm 12.5)$, 22 of which were men. IOP $(n=41)$ was reduced in all but one. We found cataract or positivity for surgery in $38(90.48 \%)$ and ptosis in 23 (54.76\%). These signs but not IOP were significantly correlated with severity of motor dysfunction. Abnormalities in ocular motility and stereopsis were observed. Conclusion: Cataract and ptosis are frequent in DM1 and associated to motor dysfunction. Reduced $\mathrm{IOP}$ is also common, but appears not to be related with motor impairment.
\end{abstract}

Keywords: myotonic dystrophy type 1, cataract, eyelid ptosis, intraocular pressure, Motor Function Measure scale, Portuguese version.

\section{RESUMO}

O objetivo do estudo foi avaliar a frequência das anormalidades oftalmológicas em uma coorte de pacientes com distrofia miotônica tipo 1 (DM1) correlacionando-as à função motora. Revisamos a fisiopatogenia da catarata e baixa pressão intraocular (PIO). Método: Os pacientes foram incluídos após diagnóstico clínico-laboratorial de DM1. Aqueles que assinaram o termo de participação foram avaliados pela escala medida da função motora, versão em português (MFM-P) e protocolo oftalmológico. Resultados: Avaliamos 42 pacientes de 17 a 64 anos (média 40,7 \pm 12,5), 22 do sexo masculino. Encontramos catarata ou positividade de cirurgia em 38 $(90,48 \%)$ e blefaroptose em 23 (54,76\%) e esses sinais foram correlacionados significativamente à maior gravidade da disfunção motora. Baixa PIO também foi comum e não correlacionada à gravidade motora. Alterações da motilidade ocular e de estereopsia ocorreram. Conclusão: Catarata e ptose palpebral são frequentes na DM1 e associadas à gravidade motora. Baixa PIO é comum e parece ser independente da evolução motora.

Palavras-chave: distrofia miotônica tipo 1, catarata, ptose palpebral, pressão intraocular, escala Medida da Função Motora, versão em português.

Myotonic dystrophy type 1 (DM1) is a cytosine-thymine-guanine [CTG]n triplet disorder inherited as autosomal dominant mode with multisystem variable expression. CTGn repeat occurs in the 3' untranslated region of the myotonin protein kinase gene (MDPK) on chromosome $19 q^{1,2,3}$. Toxic RNA transcripts accumulate in the nucleus due to aberrant splicing and lead to abnormal expression of several proteins due to sequestration of nuclear transcription factors 4 .

A variety of ocular signs is described in DM1 patients, like cataract, retinal degeneration, low intraocular pressure (IOP), eyelid ptosis, epiphora, corneal lesions, extraocular myotonia, extraocular muscle weakness, abnormal central control of eye movement ${ }^{5}$. Cataract is one of the most important and distinctive feature of the disease ${ }^{5}$ and it may alert about the underlying disease ${ }^{5}$. Therefore, ophthalmologists can help to detect DM1 patients ${ }^{6,7,8}$, to refer patients for an appropriate diagnosis, for monitoring and genetic counseling ${ }^{8}$. Also, they can help to provide the best assistance to DM1 patients, for instance, restoring their visual acuity.

Our aim was to analyze the frequency of ophthalmological findings in a cohort of DM1 patients followed up in a university hospital and to identify possible correlations of these

'Universidade Estadual de Campinas, Faculdade de Ciências Médicas, Departamento de Oftalmologia, Campinas SP, Brazil;

Universidade Estadual de Campinas, Faculdade de Ciências Médicas, Departamento de Neurologia, Campinas SP, Brazil.

Correspondence: Keila Monteiro de Carvalho; Departamento de Oftalmologia da UNICAMP; Rua Tessália Vieira de Camargo, 126 ; $13083-887$ Campinas SP,

Brasil; E-mail:keilammc@gmail.com

Conflict of interest: There is no conflict of interest to declare.

Received 06 July 2015; Received in final form 05 October 2015; Accepted 17 November 2015. 
abnormalities with motor dysfunction. We also reviewed the pathogenesis of cataract and low IOP.

\section{METHOD}

A descriptive study was carried out from February 2013 to January 2014. Consecutive patients diagnosed with DM1, from the Neuromuscular outpatient Clinic at UNICAMP University Hospital were invited to participate in the study. This study was approved by the Ethics Committee in Research of the Faculty of Medical Sciences, UNICAMP, under the protocol no. 143.693/2012. Each patient signed a written informed consent before any studyrelated procedure.

Diagnosis of DM1 was based on clinical phenotype, including distinct facial findings, facial, cervical and predominant distal weakness and atrophy, associated with action and percussion miotonia. Patients were also submitted to the motor function measure scale, Portuguese version (MFM-P) ${ }^{9}$ and ancillary exams including creatinekinase, electroneuromyography and routine laboratory tests. MFM-P scale includes 32 items, rated on a 4-point scale ( 0 to $3 ; 3=$ completes the exercise in the standard normal pattern) and 3 dimensions (D1 = standing position and transfers; D2 = axial and proximal function; D3 = distal function). The total and sub scores are expressed as percentage of the highest possible score. DNA analysis was available in $n=25$ patients. In most of these patients, screening for DMPK expansions was performed using the TP-PCR technique, which is a sensitive method but does not enable precise quantification of the CTG repeat length. The remaining patients did not have molecular testing, but for all of them there was at least one family member with a positive test and a clear autosomal dominant pattern of inheritance.

They were submitted to an ophthalmologic protocol that included: visual acuity, refraction, visual field confrontation, clinical color vision evaluation using Ishihara test, lid position, pupillary reflex, measurement of IOP, slit lamp biomicroscopy, fundus examination, motility measurements, stereopsis test, nystagmus evaluation. Visual acuity was considered with the best correction and Snellen visual acuity was converted to LogMAR acuity $^{10}$. Refraction in patients under 18 years-old was performed 30 minutes after the instillation of $1 \%$ cyclopentolate. Color vision was assessed by Ishihara's test for color deficiency, 24 plates; 2007 edition, Kanehara Trading Inc., Tokyo, Japan. Slit lamp biomicroscopy used Haag-Streit aparatus (Koeniz, Suiss). Dilated fundus examination was performed after instillation of tropicamide $1 \%$ and phenylephrine $10 \%$, using a 78 diopter lens in a Volk Optical, Mentor (Ohio, USA). IOP was recorded with Goldmann applanation tonometry (model
R900, Haag-Streit, Koeniz, Suiss) after topical anesthesia with one drop of tetracaine $1 \%$ and phenylephrine $0.1 \%$ and instillation of one drop of fluorescein 1\%. Ocular motility evaluation: the angles of deviation were measured with the best optical correction in place for the distance and the near and cardinal gaze positions. The measurements were made using the simultaneous and alternatecover tests. The Krimsky test was employed when the cover tests were not applicable. Ductions, versions and diplopia were also evaluated. Stereopsis was assessed using Titmus Stereo Fly, Circles and Animals Test (Stereo Optical Co., Inc., Chicago). Occasional patients were not able to complete some parts of the examination protocol, but the remaining tests performed were all considered for further analyses.

Statistical analysis was performed using MS-Excel (MS-Office 2010) for data organization and IBM SPSS (Statistical Package, version 22.0) for Spearman correlation test and Mann-Whitney test. Significance level was considered $<0.05$.

\section{RESULTS}

Forty-two patients were enrolled in the study, with ages ranging from 17 to 64 years $($ mean $=40.7 \pm 12.5)$, median 43.5. There were 20 men and 22 women.

Cataract or prior phacoemulsification in at least one eye was detected in 38 patients $(90.48 \%)$. Mean age at cataract diagnosis was $40.2 \pm 10.9$ years. Among 28 (73.65\%) patients that had the diagnosis of cataract made in our institution, two had visual acuity worse than 0.3 and were submitted to surgery and the others are still in visual monitoring. Ten patients with cataracts were followed up outside the institution and four (40\%) were operated. Four patients $(9.52 \%)$ in the cohort had no signs of cataract in either eye. These were one woman and three men aged 17 , 20, 23 and 30 years, respectively.

A detailed frequency of ophthalmological findings in the cohort is displayed in Table 1. Ishihara's vision color test was normal in all fourteen patients examined. Nystagmus was absent in 34 patients (80.95\%); the remaining 8 (19.05\%) had physiological nystagmus. None of the subjects presented pathological nystagmus.

The results of MFM-P scale are shown in Table 2 and Figure. Statistical analysis revealed a significant correlation between MFM-P and age ( $\mathrm{r}=-0.668$; $\mathrm{p}<0.001)$, but no correlation between IOP and MFM-P considering each eye. MFM-P also had a significant correlation with Titmus test $(r=-0.467, p=0.007)$. Patients with cataracts had lower MFM-P scores in comparison to those patients without cataracts $(75.9 \pm 14.5$ vs $95.8 \pm 2.7, \mathrm{p}=0.019)$. In addition, ptosis was also associated with lower total MFM-P scores $(73.1 \pm 15.2$ vs $84.5 \pm 12.2, \mathrm{p}=0.031)$. 


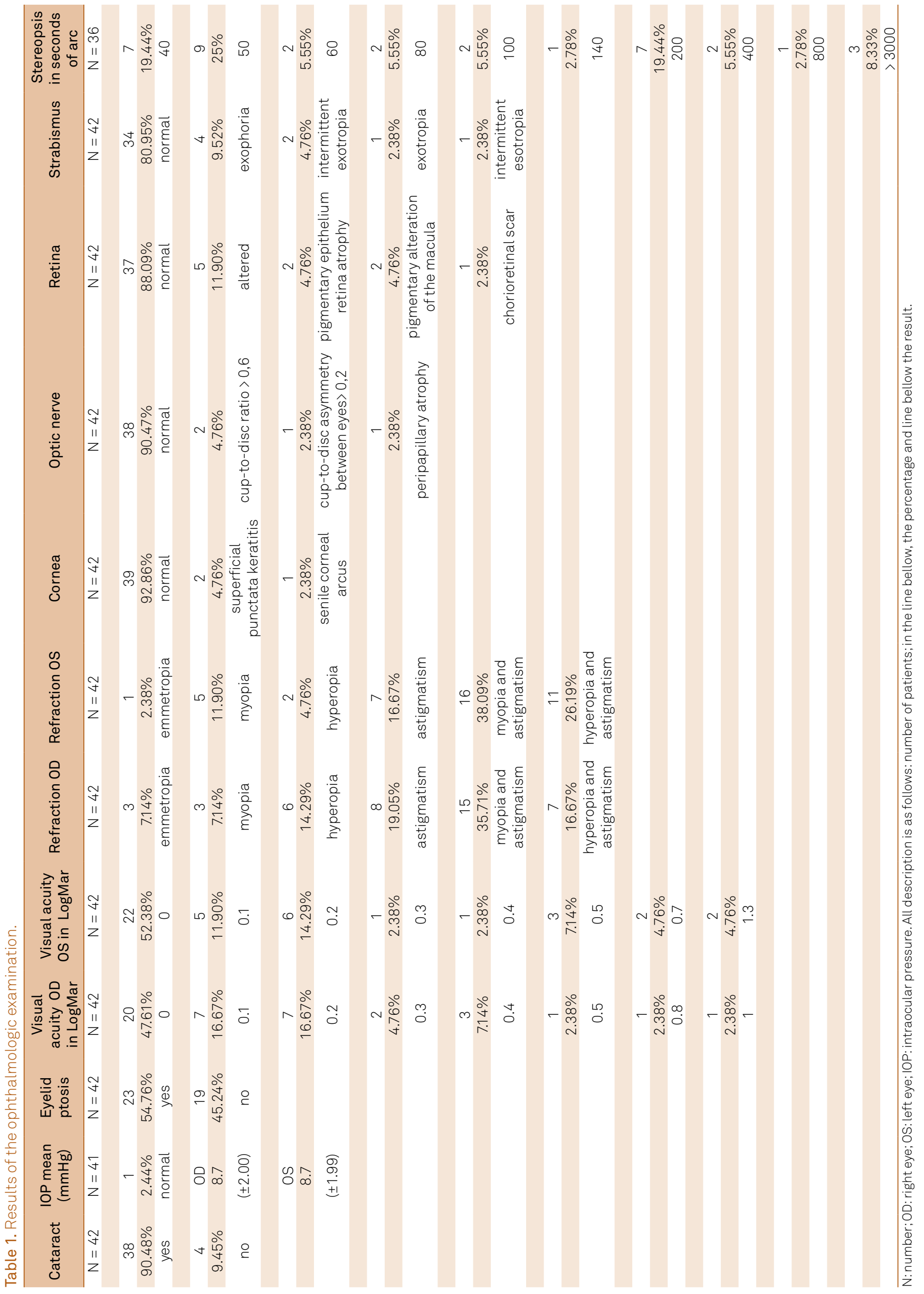


Table 2. MFM-P results in $n=36$ Myotonic Dystrophy type 1 patients.

\begin{tabular}{|c|c|c|c|c|c|}
\hline Case & Age (y) & D1 (\%) & D2 (\%) & D3 (\%) & Total (\%) \\
\hline 1 & 48 & 41.02 & 94.44 & 95.23 & 72.91 \\
\hline 2 & 60 & 33.33 & 94.44 & 80.95 & 66.66 \\
\hline 3 & 36 & 53.84 & 83.33 & 71.42 & 68.75 \\
\hline 4 & 48 & 61.53 & 77.77 & 66.66 & 68.75 \\
\hline 5 & 34 & 66.66 & 94.44 & 71.42 & 78.12 \\
\hline 6 & 57 & 58.97 & 88.88 & 80.95 & 75.00 \\
\hline 7 & 36 & 76.92 & 88.88 & 85.71 & 83.33 \\
\hline 8 & 32 & 97.43 & 100 & 90.47 & 96.87 \\
\hline 9 & 26 & 97.43 & 97.22 & 100 & 97.91 \\
\hline 10 & 57 & 79.48 & 91.66 & 100 & 88.54 \\
\hline 11 & 44 & 35.89 & 80.55 & 80.95 & 62.50 \\
\hline 12 & 34 & 87.17 & 86.11 & 95.23 & 88.54 \\
\hline 13 & 30 & 100 & 100 & 95.23 & 98.95 \\
\hline 14 & 34 & 100 & 91.66 & 90.47 & 94.79 \\
\hline 15 & 45 & 28.20 & 77.77 & 71.42 & 56.25 \\
\hline 16 & 47 & 71.79 & 91.66 & 85.71 & 82.29 \\
\hline 17 & 30 & 64.10 & 94.44 & 95.23 & 82.29 \\
\hline 18 & 31 & 74.35 & 97.22 & 95.23 & 87.50 \\
\hline 19 & 28 & 94.87 & 91.66 & 95,23 & 93.75 \\
\hline 20 & 40 & 38.46 & 97.22 & 61.90 & 65.62 \\
\hline 21 & 34 & 48.71 & 80.55 & 76.19 & 66.66 \\
\hline 22 & 37 & 25.64 & 80.55 & 80.95 & 58.33 \\
\hline 24 & 50 & 17.94 & 66.66 & 47.61 & 42.70 \\
\hline 25 & 60 & 35.89 & 88.88 & 66.66 & 62.50 \\
\hline 26 & 64 & 71.79 & 94.44 & 95.23 & 85.41 \\
\hline 27 & 61 & 25.64 & 83.33 & 61.90 & 55.20 \\
\hline 28 & 23 & 92.30 & 97.22 & 95.23 & 94.79 \\
\hline 29 & 58 & 20.51 & 93.93 & 61.90 & 54.16 \\
\hline 31 & 49 & 79.48 & 94.44 & 95.23 & 88.54 \\
\hline 32 & 40 & 61.53 & 88.88 & 85.71 & 77.08 \\
\hline 33 & 35 & 94.87 & 97.22 & 95.23 & 95.83 \\
\hline 34 & 57 & 33.33 & 83.33 & 76.18 & 61.45 \\
\hline 36 & 17 & 94.87 & 97.22 & 85.71 & 93.75 \\
\hline 38 & 30 & 92.30 & 94.44 & 95.23 & 93.75 \\
\hline 39 & 35 & 51.28 & 88.88 & 90.47 & 73.95 \\
\hline 42 & 39 & 71.79 & 86.11 & 90.47 & 81.25 \\
\hline Mean & 41.28 & 63.31 & 89.87 & 83.59 & 77.63 \\
\hline SD & 12.17 & 26.27 & 7.48 & 13.19 & 15.07 \\
\hline median & 38 & 65.38 & 91.66 & 85.71 & 79.68 \\
\hline
\end{tabular}

Y:years; MFM-P: motor function measure, Portuguese version; D1: Dimension 1 (standing position and transfers); D2: Dimension 2 (axial and proximal function); D3: Dimension 3 (distal function).

\section{DISCUSSION}

In the DM1 cohort we observed a high frequency of cataract and low IOP, the first sign with significant correlation with MFM-P. In contrast, MFM-P versus IOP was not significantly correlated. Although cataract is a cardinal sign of DM1, it generally develops with disease progression, expressed in our patients with lower scores of MFM-P. The typical DM1 lens opacity is named "christman's tree" cataract, the expression of iridescent multicolored posterior capsular lens opacity $^{11}$, at least in earlier stages of its development. This pattern is difficult to see in cases with mature cataract ${ }^{5,11,12}$.

Four patients with genetically proved DM1, aged up to 30 years, had transparent lenses and were under the mean and 
MFM-P total score

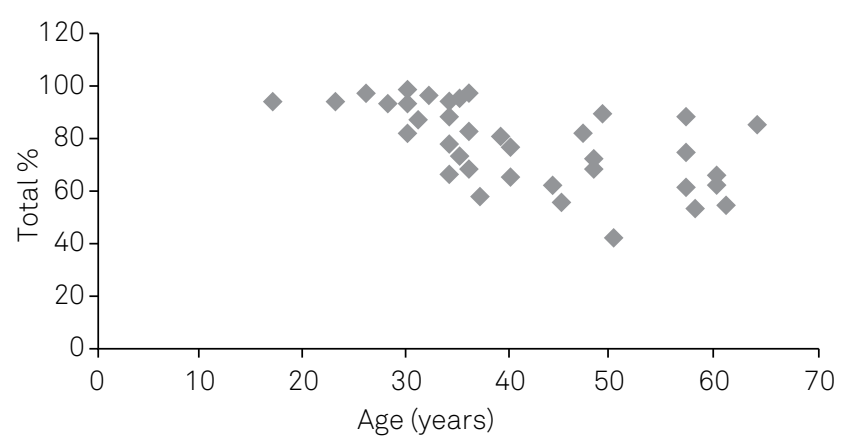

MFM-P: motor function measure scale, Portuguese version.

Figure. Distribution MFM-P total score by age.

median age in relation to those with lens opacity. This fact reinforces that cataract develops during disease evolution. It is interesting to note that MFM-P scale performed in three of them were $93.75 \%$ to $98.95 \%$, scores close to normal. Cataract is rare in congenital and infantile clinical types of DM1, at least earlier in the disease course and in patients under 10 years $^{5}$.

There are several hypotheses to explain how cataracts develop in patients with DM1: haploinsufficiency of SIX5 gene expression $^{13,14}$, toxicity of DMPK gene products ${ }^{15}$, instability of DMPK gene with repercussion in the expression profile of the epithelial cell of lens ${ }^{12}$. It is important to realize that even patients with small CTG expansions may present cataracts, and this may be the unique clinical sign in these subjects ${ }^{16}$. In this study, we were not able to correlate the frequency of cataracts with the genotypes because we employed a qualitative method (TP-PCR) for most patients and also because some patients were not tested directly.
Eyelid ptosis, not associated with external ophthalmoplegia, was the second most frequent finding in the cohort. It was significantly correlated with poor motor performance expressed by MFM-P scores, which suggests it is a manifestation that evolves along disease course. Aring et al. ${ }^{17}$ documented swollen eyelids 'pseudoptosis' in their patients younger than 18 years, while blepharoptosis was reported to be rare.

Previous reports highlighted low IOP in some patients with $\mathrm{DM}^{6,18}$. In these studies, authors hypothesized that low IOP could be related either to increased aqueous humor outflow or decreased aqueous secretion. However, a complete pathophysiologic model to explain reduced IOP is still not available $e^{6,18}$.

In our mostly adult cohort, the most common refractive error was myopia. This is in contrast to Bollinger et al. ${ }^{19}$ who described $86 \%$ of eyes with hypermetropia, +6.0 Dioptrias for children $(n=27)$ and +2.10 Dioptrias for adults $(n=5)$.

Stereopsis of 40 seconds of arc is seen in normal population $^{20}$. We found stereopsis worse than 40 in $80 \%$ of our patients. This might be explained by strabismus ${ }^{20}$, anisometropia $^{21}$, prolonged interoperative period after bilateral cataract extractions $^{22}$ or the presence of bilateral cataracts ${ }^{23}$.

We found a predominance of exodeviations in our patients, which is in line with Burian and Burns ${ }^{6}$.

In conclusion, the most frequent ophthalmologic signs in the cohort of DM1 patients, issued from a university hospital, included cataract, ptosis, low IOP, and eye movement abnormalities. Cataracts and ptosis occurred in patients with worse motor function as seen by MFM-P. IOP occurred independent of disease evolution or motor dysfunction.

\section{References}

1. Mahadevan M, Tsilfidis C, Sabourin L, Shutler G, Amemiya C, Jansen $G$ et al. Myotonic dystrophy mutation: an unstable CTG repeat in the 3' untranslated region of the gene. Science. 1992;255(5049):1253-5. doi:10.1126/science.1546325

2. Fu YH, Pizzuti A, Fenwick RG Jr, King J, Rajnarayan S, Dunne PW et al. An unstable triplet repeat in a gene related to myotonic muscular dystrophy. Science. 1992;255(5049):1256-8. doi:10.1126/science.1546326

3. Brook JD, McCurrach ME, Harley HG, et al. Molecular basis of myotonic dystrophy: expansion of a trinucleotide (CTG) repeat at the 3 ' end of transcript encoding a protein kinase family member. Cell. 1992;68(4):799-808. doi:10.1016/0092-8674(92)90154-5

4. Sicot G, Gourdon G, Gomes-Pereira M. Myotonic dystrophy, when simple repeats reveal complex pathogenic entities: new findings and future challenges. Hum Mol Genet. 2011;20 (R2):R116-23. doi:10.1093/hmg/ddr343

5. Harper PS. The eye in myotonic dystrophy. In: Harper PS editor, Myotonic dystrophy. London: WB Saunders; 2001. Chapter 8, p. 199-221.

6. Burian HM, Burns CA. Ocular changes in myotonic dystrophy. Am J Ophthalmol. 1967;63(1):22-34. doi:10.1016/0002-9394(67)90577-6
7. Kidd A, Turnpenny P, Kelly K Clark C, Church W, Hutchinson C et al. Ascertainment of myotonic dystrophy through cataract by selective screening. J Med Genet. 1995;32(7):519-23. doi:10.1136/jmg.32.7.519

8. Rojas MVM, Chimelli LMC, Simões AL. [Myotonic dystrophy type 1 in cataract patients: Molecular diagnosis for screening and genetic counseling]. Arq Bras Oftalmol. 2005;68(1):15-20. Portuguese. doi:10.1590/S0004-27492005000100004

9. Iwabe C, Miranda-Pfeilsticker BH, Nucci A. Motor function measure scale: Portuguese version and reliability analysis. Rev Bras Fisioter. 2008;12(5):417-24. doi:10.1590/S1413-35552008000500012

10. Messias A, Jorge R, Cruz AAV. [Logarithmic visual acuity charts: reasons to use and how to design it]. Arq Bras Oftalmol. 2010;73(1):96-100. Portuguese. doi:10.1590/S0004-27492010000100019

11. Reiter C, Gramer E. [Anticipation in patients with iridescent multicoloured posterior capsular lens opacities ("Christmas tree cataract"): the role in the diagnosis of myotonic dystrophy]. Ophthalmologe. 2009;106(12):1116-20. German. doi:10.1007/s00347-009-1924-2

12. Abe T, Sato M, Kuboki J, Kano T, Tamai M. Lens epithelial changes and mutated gene expression in patients with myotonic dystrophy. $\mathrm{Br} J$ Opthalmol. 1999;83(4):452-7. doi:10.1136/bjo.83.4.452 
13. Klesert TR, Cho DH, Clark JI, Maylie J, Adelman J, Snider L et al. Mice deficient in Six5 develops cataracts: implications for myotonic dystrophy. Nat Genet. 2000;25(1):105-9. doi:10.1038/75490

14. Sarkar PS, Appukuttan B, Han J, Ito Y, Ai C, Tsai W et al. Heterozygous loss of Six 5 in mice is sufficient to cause ocular cataracts. Nat Genet. 2000:25(1):110-4. doi:10.1038/75500

15. Rhodes JD, Monckton DG, McAbney JP, Prescott AR, Duncan G. Increased SK3 expression in DM1 lens cells leads to impaired growth through a greater calcium-induced fragility. Hum Mol Genet. 2006;15(24):3559-68. doi:10.1093/hmg/ddl432

16. Medica I, Teran N, Volk M, Pfeifer V, Ladavac E, Peterlin B. Patients with primary cataract as a genetic pool of DMPK protomutation. J Hum Genet. 2007;52(2):123-8. doi:10.1007/s10038-006-0091-4

17. Aring E, Ekström AB, Tulinius M, Sjöström A. Ocular motor function in relation to gross motor function in congenital and childhood myotonic dystrophy type 1. Acta Ophthalmol. 2012;90(4):369-74. doi:10.1111/j.1755-3768.2010.01956.x

18. Rosa N, Lanza M, Borrelli M, Palladino A, Di Gregorio MG, Politano L. Intraocular pressure and corneal biomechanical properties in patients with myotonic dystrophy. Ophthalmology 2009;116(2):231-34. doi:10.1016/j.ophtha.2008.09.001

19. Bollinger KE, Kattouf V, Arthur B, Weiss AH, Kivlin J, Kerr N et al. Hypermetropia and esotropia in myotonic dystrophy. J AAPOS. 2008;12(1):69-71. doi:10.1016/j.jaapos.2007.08.005

20. Bicas HEA, Almeida HC. Funções visuais binoculares. In: Bicas HEA, Souza-Dias CR, Almeida HC, editors. Estrabismo. Rio de Janeiro: Guanabara Koogan; 2008. p. 97. (Série Oftalmologia Brasileira).

21. Dadeya S, Kamlesh, Shibal F. The effect of anisometropia on binocular visual function. Indian J Ophthalmol. 2001;49(4):261-3.

22. Loba P, Rajska K, Simiera J, Wilczynski M, Omulecki W, Broniarczyk-Loba A. The influence of a prolonged interoperative period on binocular vision after bilateral cataract extractions. Eur J Ophthalmol. 2015;25(4):315-9. doi:10.5301/ejo.5000569

23. Manoranjan A, Shrestha S, Shrestha S. Effect of bilateral agerelated cataract on stereoacuity. Strabismus. 2013;21(2):116-22. doi:10.3109/09273972.2013.786747 